Research Article

\title{
Study on Variation of Surface Runoff and Soil Moisture Content in the Subgrade of Permeable Pavement Structure
}

\author{
Lijun Hou, ${ }^{1}$ Yuan Wang, ${ }^{1}$ Fengchun Shen, ${ }^{1}$ Ming Lei, ${ }^{1}$ Xiang Wang, ${ }^{1}$ Xiaochong Zhao, ${ }^{2}$ \\ Shuling Gao $\mathbb{D}^{2}{ }^{2}$ and Abdullah Alhaj ${ }^{3}$ \\ ${ }^{1}$ Power China Roadbridge Group Co., Ltd., Beijing 100048, China \\ ${ }^{2}$ School of Civil Engineering and Transportation, Hebei University of Technology, Tianjin 300401, China \\ ${ }^{3}$ Department of Geosciences and Geological and Petroleum Engineering, Missouri University of Science and Technology, Rolla, \\ MO 65409, USA
}

Correspondence should be addressed to Shuling Gao; gsl200001@126.com

Received 17 May 2020; Revised 10 June 2020; Accepted 13 June 2020; Published 4 July 2020

Academic Editor: Yifeng Ling

Copyright (c) 2020 Lijun Hou et al. This is an open access article distributed under the Creative Commons Attribution License, which permits unrestricted use, distribution, and reproduction in any medium, provided the original work is properly cited.

\begin{abstract}
The self-designed indoor simulated rainfall device was used to rain on five types of pavement structures with 4 types of rainfall intensity $(2.5 \mathrm{~mm} / \mathrm{min}, 3.4 \mathrm{~mm} / \mathrm{min}, 4.6 \mathrm{~mm} / \mathrm{min}$, and $5.5 \mathrm{~mm} / \mathrm{min})$. The effect of rainfall intensity on the surface runoff, the relation between the subgrade soil moisture content changes, and the influence of initial soil water content on rain infiltration rate are studied. The test results show that the surface runoff coefficient of densely asphalted pavement is greater than $90 \%$ in drainage pavements and it has little influence on the reducing and hysteresis of the flood peak. The surface runoff coefficient of large-void asphalt pavement (permeable) is less than $40 \%$. Although the large-void asphalt pavement (permeable) can reduce a small amount of surface runoff, it has no obvious effect on the reduction and hysteresis of the flood peak. In semipermeable pavement, with the increasing of the thickness of base (graded gravel), the surface runoff coefficient decreases at different rainfall intensities, parts of the surface runoff are reduced, and the arrival of flood peaks is delayed. In permeable roads, almost no surface runoff occurred. As time continued, the soil moisture content quickly reached a saturated state and presented a stable infiltration situation under the action of gravity and the gradient of soil water suction. As the initial moisture content increases, the initial infiltration rate decreases and the time to reach a stable infiltration rate becomes shorter. The drier the soil, the greater the initial infiltration rate and the higher the soil moisture content after infiltration stabilization. Permeable roads can greatly alleviate the pressure of urban drainage and reduce the risk of storms and floods.
\end{abstract}

\section{Introduction}

According to China's National Bureau of Statistics, China's urbanization rate had reached $57.35 \%$ in 2016 [1]. The densely asphalted road surface has increased significantly. During rain and snow, the accumulated water on the road surface causes serious inconvenience to pedestrian travel and vehicle driving. In the case of heavy rainfall, a large surface runoff will occur, increasing the drainage burden of the urban pipe network [2]. In addition, due to lack of rainwater penetration, groundwater is not effectively supplied, and many cities face severe water shortages and droughts [3, 4]. Since 1970, the United States, the United
Kingdom, and Australia have successively developed a series of technologies to control urban runoff and introduced a series of rainwater management plans and guidelines [5-16].

Since October 2014, China has put forward the development strategy of "sponge city" urbanization on the basis of summarizing the concept of rainwater control in foreign cities. A series of policies and technical guidelines were issued.

At present, researchers are focusing on the effects of surface runoff control on permeable pavement structures (drainage pavements, semipermeable pavements, and permeable roads) [1-5]. 
Zhu [1] used storm water management model (SWMM) software to simulate the effects of different permeable pavement structures under different rainfall conditions on reducing surface runoff and controlling flood peaks. Guan [2] simulated the variation of surface runoff and soil moisture content in the subgrade of permeable roads. Xu [17] studied the relationship between rainfall and runoff in the area under four different underlying conditions by distributed water stability model. Cai [18] used SWMM to simulate the runoff and drainage condition under different rainfall conditions in Guangzhou. Zhao [19] studied the rainfall runoff model and runoff reduction of permeable asphalt pavement. The results show that the thickness of the pavement structural layer, the initial soil moisture content, and the saturated moisture content have a greater influence on the permeable function of the pavement.

However, it is not enough to study the comparative effects of three permeable pavement structures on urban rainwater surface runoff. The correlation between the base layer thickness and surface runoff and the change of soil moisture content in roadbed with time need to be studied further.

In order to study the influence of three types of permeable pavement structures on urban rainwater surface runoff, four types of artificial rainfall intensity $(2.5 \mathrm{~mm} / \mathrm{min}$, $3.4 \mathrm{~mm} / \mathrm{min}, 4.6 \mathrm{~mm} / \mathrm{min}$, and $5.5 \mathrm{~mm} / \mathrm{min}$ ) will be used to study five types of pavement structure section types used by self-designed indoor simulated rainfall device. Furthermore, the effect of base layer thickness on surface runoff, the relationship between soil moisture content and time, and the influence of initial soil moisture content on rainwater infiltration rate were analyzed.

The objective of this study is to provide more theoretical basis for the application of permeable pavement structure and theoretical support for the "sponge city."

\section{Road Conditions}

Urban roads are generally composed of traffic lanes, bicycle lanes, and sidewalks. These three types of roads have different requirements on traffic load and the distribution of drainage facilities.

Traffic lanes are mainly bearing urban traffic loads, while structural mechanics index and durability should also meet the requirements of traffic load except reducing the surface runoff. Therefore, the drainage road is adopted.

The load of bicycle lanes is smaller than that of traffic lanes, so semipermeable pavement is adopted. And the load of sidewalks is the least, while permeable road is adopted. The pavement lane distribution diagram is illustrated in Figure 1.

\section{Rainfall Design}

Four types of rainfall intensities were obtained from the average annual rainfall intensity in Huangdao District of Qingdao City in Shandong Province in China in recent years, which were $2.5 \mathrm{~mm} / \mathrm{min}, 3.4 \mathrm{~mm} / \mathrm{min}, 4.6 \mathrm{~mm} / \mathrm{min}$, and $5.5 \mathrm{~mm} / \mathrm{min}$, respectively, whose rainfall time was all lasting for $120 \mathrm{~min}$.

The relationship between cumulative rainfall and rainfall duration is shown in Figure 2.

\section{Pervious Pavement Structure}

According to the technical specification of permeable asphalt pavement (CJJ/T190-2012) [20], the structures of drainage pavement, semipermeable pavement, and permeable pavement were studied, respectively.

In the drainage pavement structure, large-void asphalt mixture was only used for surface layer. Impervious asphalt material or asphalt sealing coating was used on the base layer, and rainwater was discharged from the surface of the sealing layer without penetrating below the base layer. This approach is generally applied to the roadway as shown in Figure 3.

In the semipermeable pavement structure, the surface layer adopted large-void asphalt mixture. The base layer adopted permeable graded gravel, and the cushion layer adopted medium sand. This kind of pavement structure is generally applied to the bicycle lanes, as shown in Figure 4.

In the permeable roads structure, the surface layer adopts large-void asphalt mixture. The base layer adopted permeable graded gravel, and the cushion was generally made of medium sand, while subgrade was made of sand with better permeability. This kind of pavement structure was generally applied to sidewalks as shown in Figure 5.

Polypropylene fiber can be used in cement-based materials to improve the toughness and anticracking performance of the matrix composite [21-23]. But, polypropylene fiber cannot bear high temperature, while basalt fiber not only can improve the material's bending resistance [24] but also can bear high temperature in asphalt concrete. So, basalt fiber is very suitable for use in large-void asphalt concrete.

As shown in Figures 3-5, the surface layer used a largevoid basalt fiber asphalt mixture, whose void ratio was $19.3 \%$. Its permeability coefficient was $3.35 \times 10^{-2} \mathrm{~cm} / \mathrm{s}$ and the transverse slope of the surface layer was $2 \%$.

The base layer was made of graded crushed stone, whose void ratio was $38 \%$. In order to reduce the surface runoff of the large-void asphalt pavement, the base layer thickness was not less than $15 \mathrm{~cm}$.

The cushion layer used medium sand with a particle size of $1.3 \mathrm{~mm}$, and its permeability coefficient was $2.4 \times 10^{-3} \mathrm{~cm} / \mathrm{s}$.

The soil foundation used sandy soil and the soil permeability coefficient after compaction was $1 \times 10^{-3} \mathrm{~cm} / \mathrm{s}$.

When the basalt fiber content was $0.3 \%$, the indicators of each road performance reach the optimum. The test results are shown in Table 1.

\section{Artificial Simulated Rainfall Experiment}

5.1. Experimental Device. The artificial rainfall equipment was composed of test chamber, storage bucket, pump, water meter, and sprinkler. 


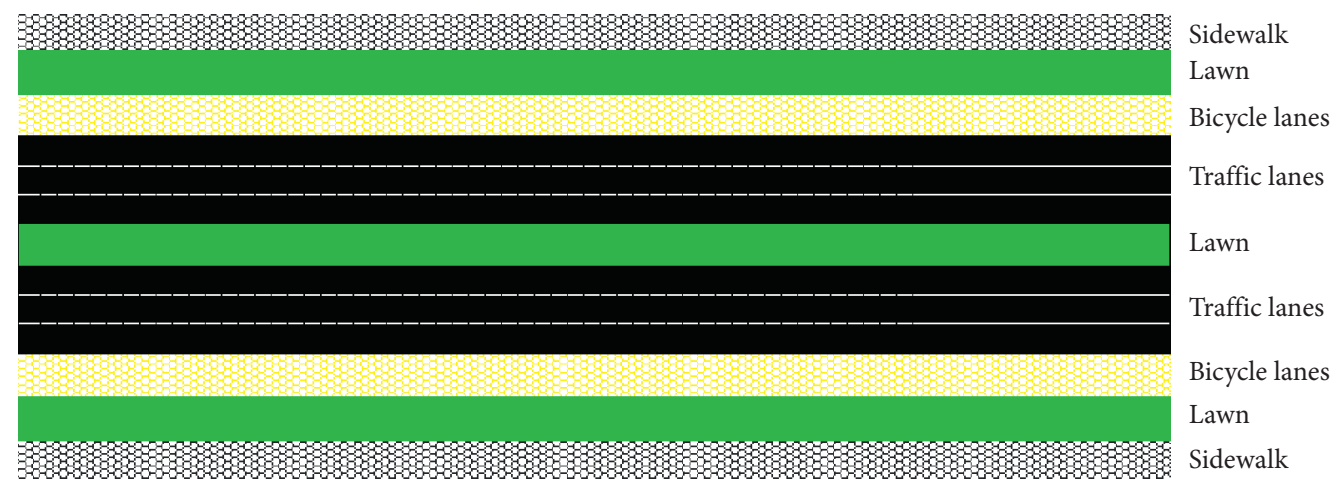

Figure 1: Pavement lane distribution.

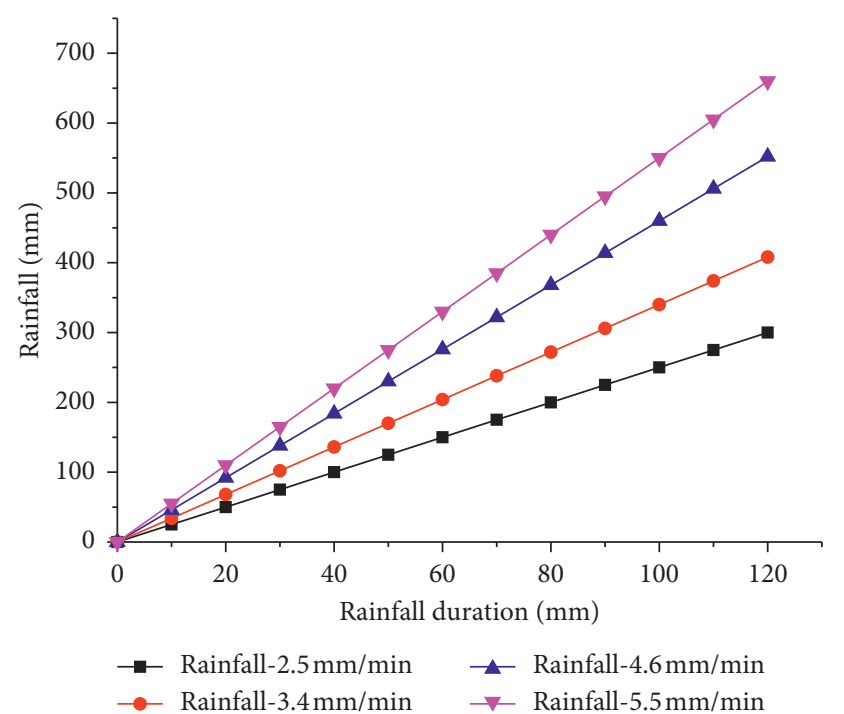

FIgURE 2: The relationship between cumulative rainfall and rainfall duration.

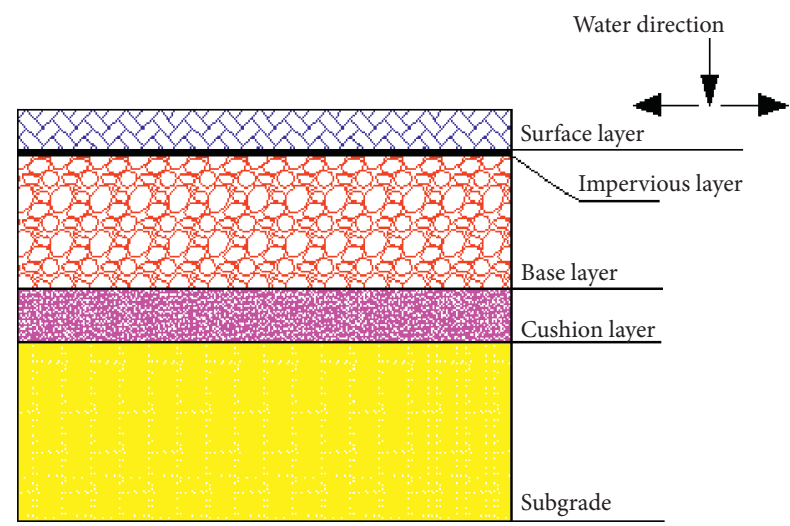

FIgURE 3: Drainage pavement structure.

As shown in Figures 6(a) and 6(b), the length, width, and height of the test chamber were $90 \mathrm{~cm}, 90 \mathrm{~cm}$, and $100 \mathrm{~cm}$, respectively. The one side of the test chamber shall be installed with transparent glass to observe the wetting front, and the box shall be paved with large-void asphalt pavement structure layer (surface layer, base layer, cushion layer, and

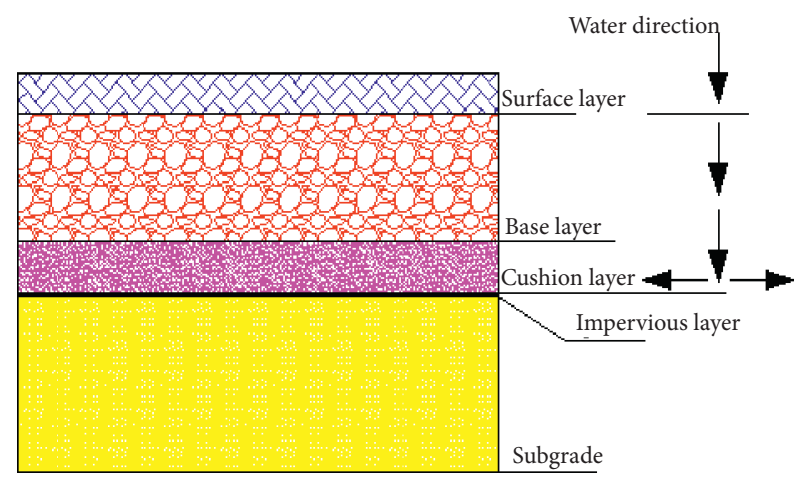

Figure 4: Semipermeable pavement structure.

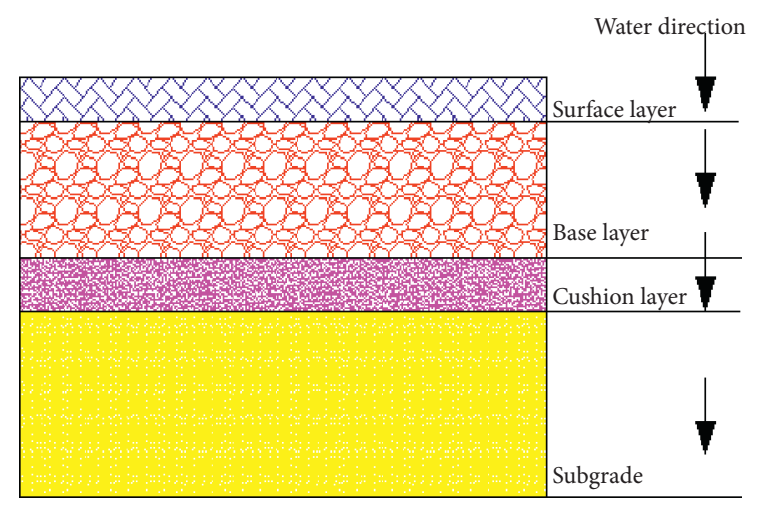

FIGURE 5: Permeable road structure.

subgrade). The other three sides of the box were provided with a certain number of drainage holes in order to collect surface runoff and the water discharged from the surface of the impervious sealing coating. There were drainage holes at the bottom of the box to collect the amount of rainwater seepage from the roadbed.

The water in the bucket was sent to the sprinkler by pump as shown in Figure 6(c). In order to simulate different rainfall intensities, the tee at the outlet of the pump was connected.

One pipe (Figure 6(c)-1) provided water and the other pipe (Figure 6(c)-2) controlled the different rainfall intensity by a valve in the water pipe. 
TABLE 1: The indicators of large-void basalt fiber asphalt mixture (fiber content was $0.3 \%$ ).

\begin{tabular}{lcc}
\hline \multicolumn{2}{c}{ The indicators of performance test } & Test results \\
\hline High-temperature rutting experiment & Dynamic stability (time $\left.\cdot \mathrm{mm}^{-1}\right)$ & 4091 \\
Freeze-thaw splitting test & Splitting tensile strength $(\mathrm{MPa})$ & 0.60 \\
& Bending strength $(\mathrm{MPa})$ & 10.75 \\
Low-temperature bending test $\left(-10^{\circ} \mathrm{C}\right)$ & Maximum bending strain $(\mu \varepsilon)$ & 4957 \\
& Bending stiffness modulus $(\mathrm{MPa})$ & 2172 \\
Uniaxial compression experiment & Compressive strength $(\mathrm{MPa})$ & 4.50 \\
\hline
\end{tabular}

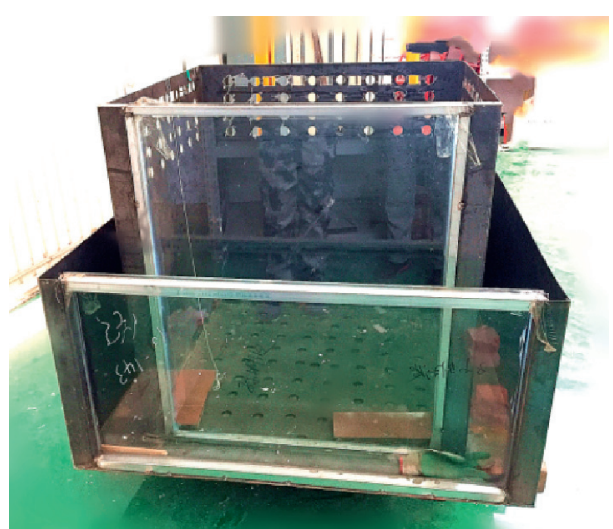

(a)

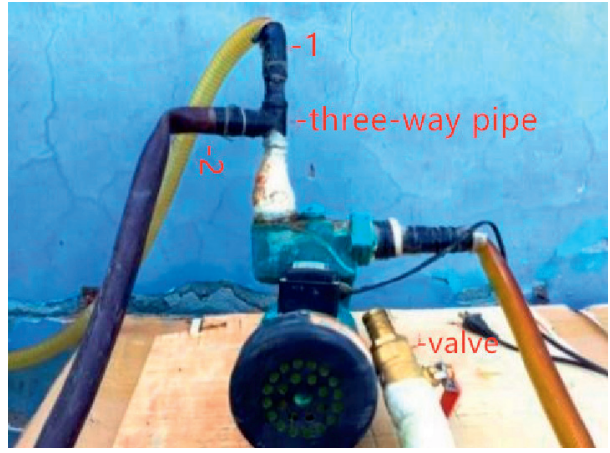

(c)

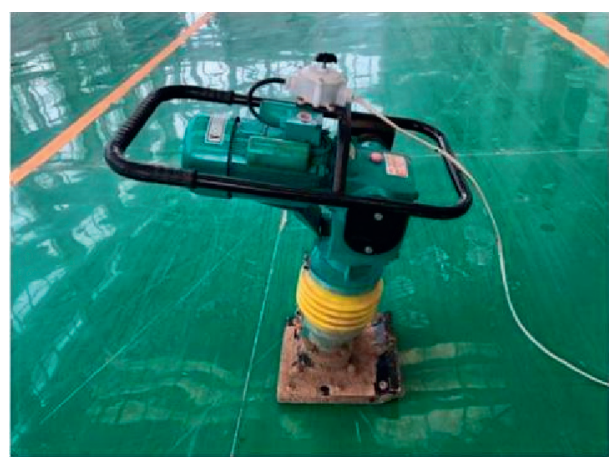

(e)

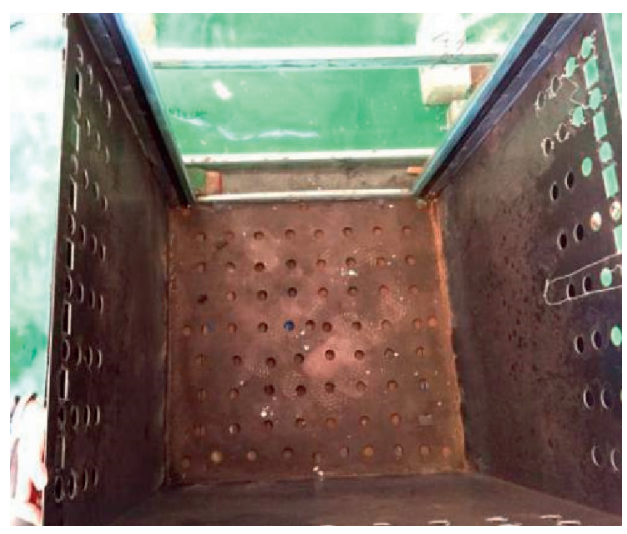

(b)

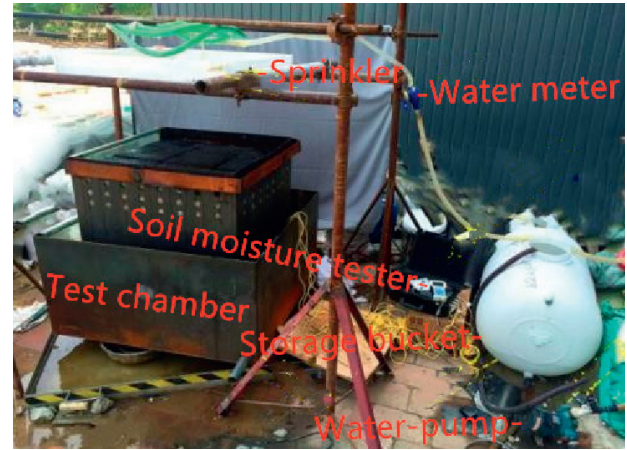

(d)

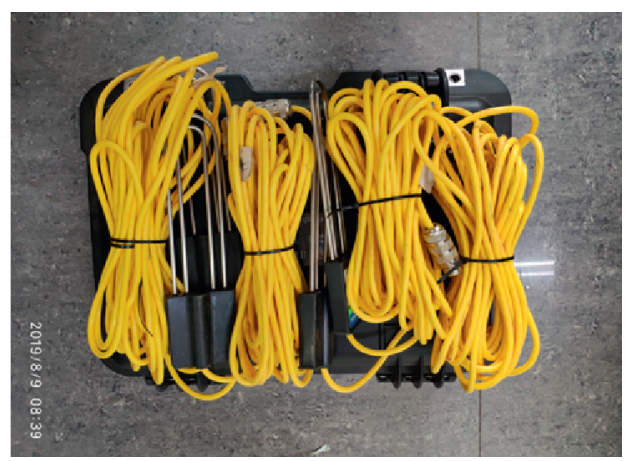

(f)

Figure 6: Artificial rainfall experiment device, (a) test chamber, (b) the bottom of test chamber, (c) pump, (d) rainfall equipment, (e) impact tamping, and (f) moisture tester.

Water meters were used to record the amount of water passing through. The sprinklers were made of plastic, whose length, width, and height were $90 \mathrm{~cm}, 86.5 \mathrm{~cm}$, and $15 \mathrm{~cm}$, respectively.
In order to monitor the occurrence and ending time of surface runoff and surface runoff values under different rainfall intensities, a certain number of drainage holes were dug at a position that was parallel to the surface layer to 
TABLE 2: Different pavement structure section types.

\begin{tabular}{lc}
\hline Number & Sectional type of pavement structure \\
\hline 1 & Dense asphalt mixture surface layer $5 \mathrm{~cm}+$ base layer $30 \mathrm{~cm}+$ cushion layer $8 \mathrm{~cm}+$ subgrade $50 \mathrm{~cm}$ \\
2 & Large-void asphalt mixture surface layer $5 \mathrm{~cm}+$ base layer $30 \mathrm{~cm}+$ cushion layer $8 \mathrm{~cm}+$ subgrade $50 \mathrm{~cm}$ \\
3 & Large-void asphalt mixture surface layer $5 \mathrm{~cm}+$ base layer $25 \mathrm{~cm}+$ cushion layer $8 \mathrm{~cm}+$ subgrade $55 \mathrm{~cm}$ \\
4 & Large-void asphalt mixture surface layer $5 \mathrm{~cm}+$ base layer $20 \mathrm{~cm}+$ cushion layer $8 \mathrm{~cm}+$ subgrade $60 \mathrm{~cm}$ \\
5 & Large-void asphalt mixture surface layer $5 \mathrm{~cm}+$ base layer $15 \mathrm{~cm}+$ cushion layer $8 \mathrm{~cm}+$ subgrade $65 \mathrm{~cm}$ \\
\hline
\end{tabular}

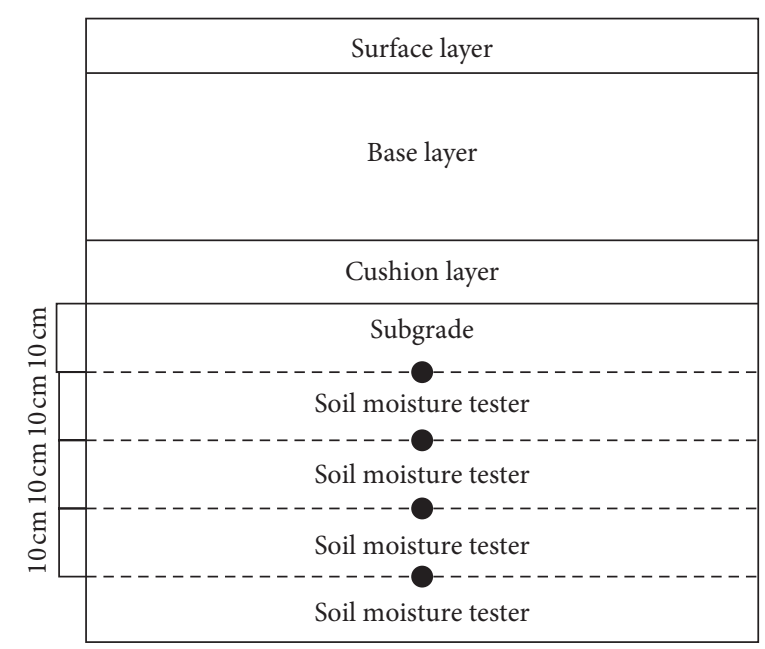

Figure 7: Schematic diagram of moisture analyzer layout.

collect rainwater from the surface runoff. The drainage hole diameter was $0.07 \mathrm{~cm}$, who was dug at intervals of $3 \mathrm{~cm}$. The water in each drainage hole can be collected into the same container through the surrounding sinks as shown in Figure 6(d).

In order to monitor the starting time, ending time, and seepage flow of different rainfall intensities, the water penetrated to the bottom of the pavement structure was collected in a collection container and determined by measuring the amount of water in the container. The artificial rainfall experiment equipment and devices are shown in Figure 6.

5.2. Experimental Process. The artificial simulated rainfall experimental device was used to test 5 types of structural section. The pavement structure is shown in Table 2 .

In order to measure the change of soil water content during and after rainfall, 4 soil moisture analyzers were embedded in the soil to measure the soil water change at different depths. The layout diagram is shown in Figures 7 and 8 .

\section{Analysis of Experimental Results}

6.1. Drainage Pavement (Travel Lane). Artificial rainfall experiments were performed on the 1 and 2 cross-section types by using 4 types of rainfall intensity $(2.5 \mathrm{~mm} / \mathrm{min}$, $3.4 \mathrm{~mm} / \mathrm{min}, 4.6 \mathrm{~mm} / \mathrm{min}$, and $5.5 \mathrm{~mm} / \mathrm{min}$ ).

The expression of surface runoff coefficient is shown in the following formula:

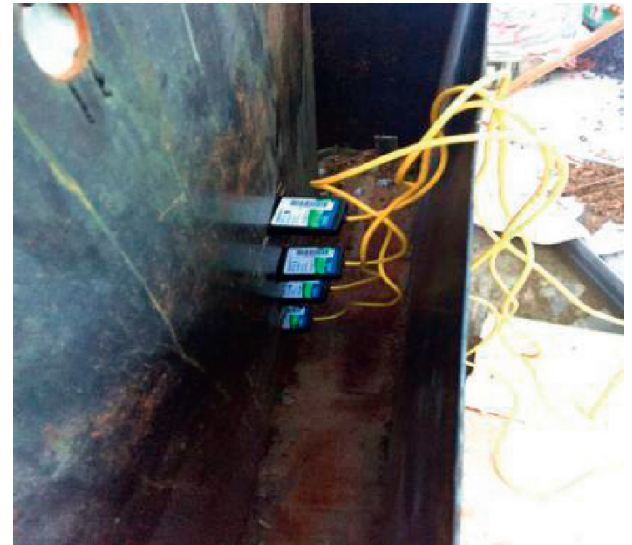

Figure 8: Moisture tester layout.

surface runoff coefficient $=\frac{\text { surface runoff }}{\text { total } \text { rainfall }} \times 100 \%$.

The surface runoff and surface runoff coefficient are shown in Table 3.

The structural section of types 1 and 2 is shown in Figure 9; as the rainfall intensity was $4.6 \mathrm{~mm} / \mathrm{min}$, the runoff of rainwater lasted for 60 minutes.

As can be seen from Figure 10(a), when dense asphalt mixture was used as the surface layer, almost all the rainwater was discharged from the slope surface of the road surface and formed surface runoff.

As can be seen from Figure 10(b), when the large-void asphalt mixture was used as the surface layer, only a small 
TABLE 3: Surface runoff coefficients at different rainfall intensities.

\begin{tabular}{|c|c|c|c|c|c|c|c|c|}
\hline \multirow[b]{2}{*}{$\begin{array}{l}\text { Structural } \\
\text { section type }\end{array}$} & \multicolumn{2}{|c|}{$5.5 \mathrm{~mm}(\mathrm{~min})$} & \multicolumn{2}{|c|}{$4.6 \mathrm{~mm}(\mathrm{~min})$} & \multicolumn{2}{|c|}{$3.4 \mathrm{~mm}(\mathrm{~min})$} & \multicolumn{2}{|c|}{$2.5 \mathrm{~mm}(\mathrm{~min})$} \\
\hline & $\begin{array}{c}\text { Surface } \\
\text { runoff } \\
(\mathrm{mm})\end{array}$ & $\begin{array}{l}\text { Surface runoff } \\
\text { coefficient }(\%)\end{array}$ & $\begin{array}{c}\text { Surface } \\
\text { runoff } \\
(\mathrm{mm})\end{array}$ & $\begin{array}{l}\text { Surface runoff } \\
\text { coefficient }(\%)\end{array}$ & $\begin{array}{c}\text { Surface } \\
\text { runoff } \\
(\mathrm{mm})\end{array}$ & $\begin{array}{l}\text { Surface runoff } \\
\text { coefficient }(\%)\end{array}$ & $\begin{array}{c}\text { Surface } \\
\text { runoff } \\
(\mathrm{mm})\end{array}$ & $\begin{array}{l}\text { Surface runoff } \\
\text { coefficient }(\%)\end{array}$ \\
\hline 1 & 630 & 95.5 & 520 & 94.2 & 380 & 93.1 & 277 & 92.3 \\
\hline 2 & 240 & 36 & 160 & 29 & 50 & 12 & 9 & 3 \\
\hline
\end{tabular}

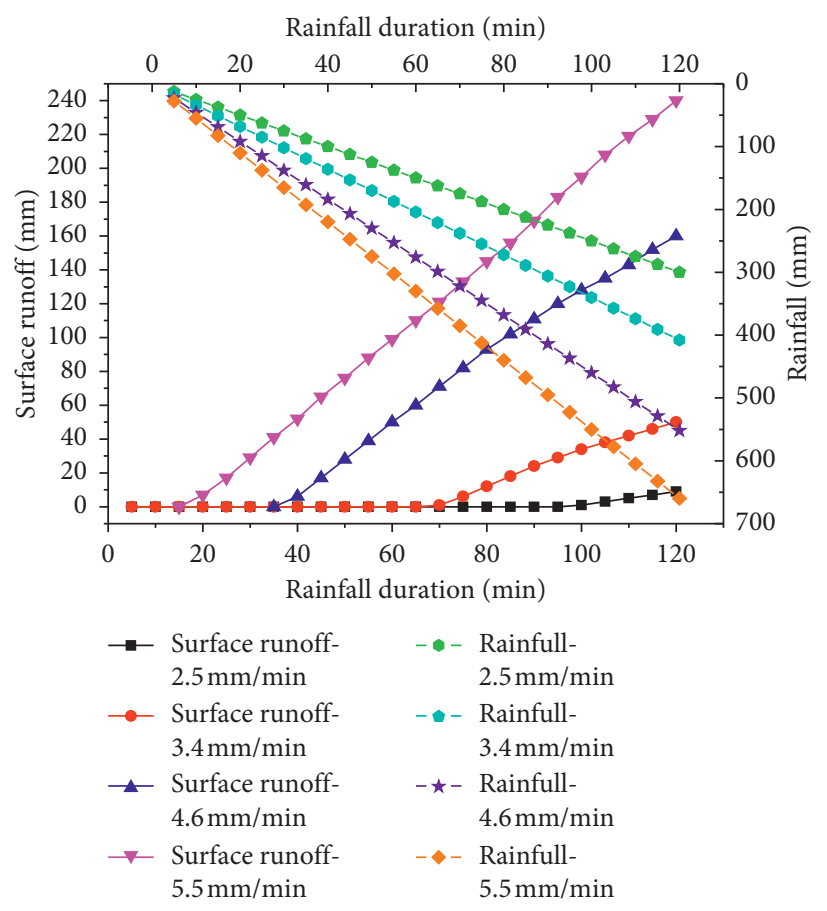

FIGURE 9: Large-void asphalt pavement.

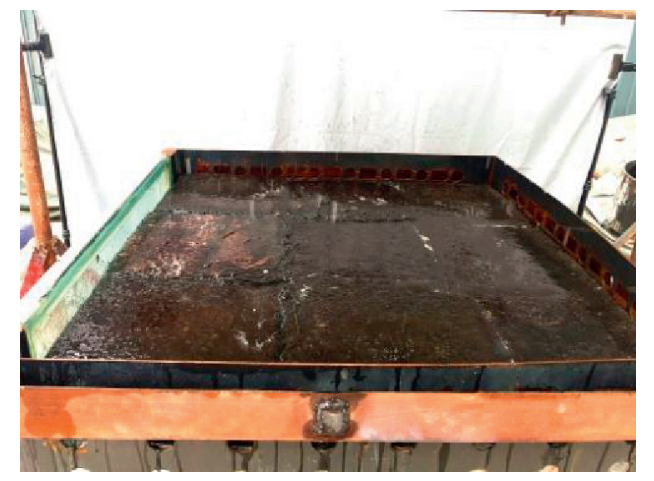

(a)

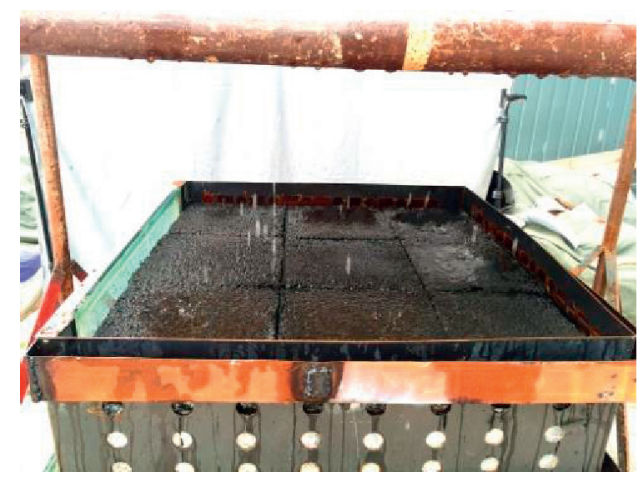

(b)

Figure 10: Rain intensity $4.6 \mathrm{~mm} / \mathrm{min}$ (when the rainfall lasted $60 \mathrm{~min}$ ). (a) Structural section type 1. (b) Structural section type 2.

part of the rain water was discharged from the slope surface of the road surface and formed surface runoff.

Under the conditions of different rainfall intensity, the relationship between the surface runoff and the rainfall duration is shown in Figures 9 and 11 about the structure section types 1 and 2.

As can be seen from Figure 11, the porosity of the dense asphalt mixture was $4 \%$ and the surface was almost impermeable. When the rainfall lasted for 5 minutes, the corresponding surface runoff was $5 \mathrm{~mm}, 9 \mathrm{~mm}, 16 \mathrm{~mm}$, and $22 \mathrm{~mm}$ corresponding to the rainfall intensity with $2.5 \mathrm{~mm} /$ $\mathrm{min}, 3.4 \mathrm{~mm} / \mathrm{min}, 4.6 \mathrm{~mm} / \mathrm{min}$, and $5.5 \mathrm{~mm} / \mathrm{min}$. When the rainfall lasted for 120 minutes, the corresponding surface runoff was $277 \mathrm{~mm}, 380 \mathrm{~mm}, 520 \mathrm{~mm}$, and $630 \mathrm{~mm}$ and the corresponding surface runoff coefficients were $92.3 \%, 93.1 \%$, $94.2 \%$, and $95.5 \%$. And the rainwater almost flowed into the water tank. 


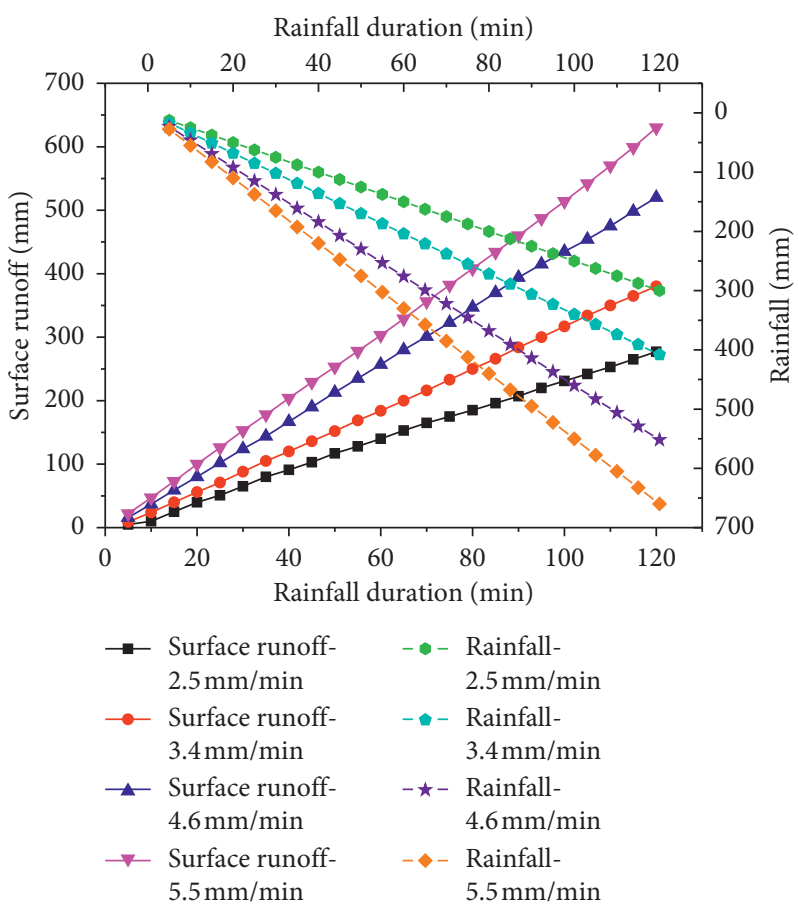

FIGURE 11: Dense asphalt pavement.

As can be seen from Figure 9, when the rainfall intensity was $2.5 \mathrm{~mm} / \mathrm{min}$ and the rainfall lasted for 99 minutes, surface runoff began to occur. When the rainfall lasts for 120 minutes, the surface runoff was $9 \mathrm{~mm}$, and the rest of the rainwater penetrated into the impermeable sealing coating and flowed into the tank through the drainage hole.

When the rainfall intensity was $3.4 \mathrm{~mm} / \mathrm{min}$ and the rainfall lasted for 70 minutes, surface runoff began to be generated. When the rainfall lasted for 120 minutes, the surface runoff was $50 \mathrm{~mm}$.

When the rainfall intensity was $4.6 \mathrm{~mm} / \mathrm{min}$ and the rainfall lasted for 40 minutes, surface runoff began to be generated. When the rainfall lasted for 120 minutes, the surface runoff was $160 \mathrm{~mm}$.

When the rainfall intensity was $5.5 \mathrm{~mm} / \mathrm{min}$ and the rainfall lasted for 20 minutes, surface runoff began to be generated. When the rainfall lasted for 120 minutes, the surface runoff was $240 \mathrm{~mm}$.

The corresponding surface runoff coefficients of the four rainfall intensities were $0.03,0.12,0.29$, and 0.36 . With the increasing of rainfall intensity, the surface runoff coefficient gradually increased, and the generation time of surface runoff was also earlier.

The reason for this phenomenon can be analyzed by the flow generation mechanism of large-void asphalt pavement as shown by part 6 in this paper. The experiment shows that the large-void asphalt pavement can greatly reduce the surface runoff compared with dense asphalt pavement.

6.2. Semipermeable Road (Bicycle Lane). Four types of thickness of $30 \mathrm{~cm}, 25 \mathrm{~cm}, 20 \mathrm{~cm}$, and $15 \mathrm{~cm}$ (corresponding to pavement structure section types $2,3,4$, and 5) were used to study the influence of the base layer thickness on surface runoff.

According to the experimental data in Table 4, when the rainfall intensity was $5.5 \mathrm{~mm} / \mathrm{min}$, the surface runoff coefficients were $5 \%, 13 \%, 20 \%$, and $26 \%$ corresponding to the base layer thickness of $30 \mathrm{~cm}, 25 \mathrm{~cm}, 20 \mathrm{~cm}$, and $15 \mathrm{~cm}$. Therefore, as the increase of the base layer thickness, the surface runoff can be effectively reduced.

The permeability of the cushion was relatively small so that was used as the base layer. When the rainfall intensity was relatively high, the rainwater that penetrated from the surface layer of the large-void asphalt pavement cannot be discharged in time, while the base can temporarily store rainwater, so as to reduce the surface runoff.

The surface runoff was closely related to the thickness and voids of the base.

When the rainfall intensity was $2.5 \mathrm{~mm} / \mathrm{min}$, no surface runoff occurred on the 4 thickness pavement layers. So, the surface runoff coefficient was greatly affected by the thickness of water storage reservoir and rainfall intensity.

6.3. Permeable Road (Sidewalk). The variation of soil moisture content with rainfall intensity in the soil foundation and the effect of initial soil moisture content on rainwater infiltration were studied by four types of rainfall intensity of Section 2 pavement structure. The experimental results are shown in Table 5 .

The surface runoff was $30 \mathrm{~mm}$, when the rainfall intensity was $5.5 \mathrm{~mm} / \mathrm{min}$ and the rainfall lasted for $120 \mathrm{~min}$, while the surface runoff was $5 \mathrm{~mm}$, when the rainfall intensity was $4.6 \mathrm{~mm} / \mathrm{min}$ and the rainfall lasted for $120 \mathrm{~min}$. The rainfall intensity was $3.4 \mathrm{~mm} / \mathrm{min}$ and $2.5 \mathrm{~mm} / \mathrm{min}$, 


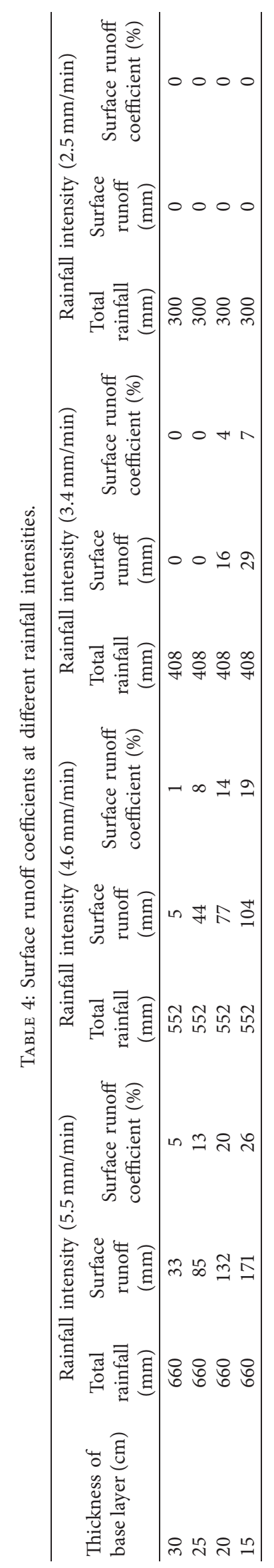


TABLE 5: Surface runoff coefficients at different rainfall intensities.

\begin{tabular}{|c|c|c|c|c|c|c|c|c|}
\hline \multirow[b]{2}{*}{$\begin{array}{l}\text { Structural } \\
\text { section type }\end{array}$} & \multicolumn{2}{|c|}{$5.5 \mathrm{~mm}(\mathrm{~min})$} & \multicolumn{2}{|c|}{$4.6 \mathrm{~mm}(\mathrm{~min})$} & \multicolumn{2}{|c|}{$3.4 \mathrm{~mm}(\mathrm{~min})$} & \multicolumn{2}{|c|}{$2.5 \mathrm{~mm}(\mathrm{~min})$} \\
\hline & $\begin{array}{c}\text { Surface } \\
\text { runoff } \\
(\mathrm{mm})\end{array}$ & $\begin{array}{l}\text { Surface runoff } \\
\text { coefficient }(\%)\end{array}$ & $\begin{array}{c}\text { Surface } \\
\text { runoff } \\
(\mathrm{mm})\end{array}$ & $\begin{array}{l}\text { Surface runoff } \\
\text { coefficient }(\%)\end{array}$ & $\begin{array}{c}\text { Surface } \\
\text { runoff } \\
(\mathrm{mm})\end{array}$ & $\begin{array}{l}\text { Surface runoff } \\
\text { coefficient }(\%)\end{array}$ & $\begin{array}{c}\text { Surface } \\
\text { runoff } \\
(\mathrm{mm})\end{array}$ & $\begin{array}{l}\text { Surface runoff } \\
\text { coefficient }(\%)\end{array}$ \\
\hline 2 & 30 & 5 & 5 & 1 & 0 & 0 & 0 & 0 \\
\hline
\end{tabular}

respectively; there is no surface runoff during $120 \mathrm{~min}$ rainfall.

As the rainfall continued, the large-void asphalt pavement structure tended to saturate and the rain began to penetrate from the subgrade. So, the amount of rainwater stored in the pavement was the difference between the rainfall and the permeability amount of the soil. The relationship between storage under various rainfall intensities and time is shown in Figure 12.

As can be seen from Figure 13, when the rainfall intensity was $5.5 \mathrm{~mm} / \mathrm{min}$, the infiltration started after 42 minutes. All the rainwater fallen was stored in the pavement structure during 42 minutes. As rainfall continued, the rainwater penetrated from the roadbed was less than the rainfall and the rainwater storage capacity of the pavement structure. The rainfall lasted more than 14 hours from start to the end of the infiltration, and the infiltration rainfall was $535 \mathrm{~mm}$.

When the rainfall intensity was $4.6 \mathrm{~mm} / \mathrm{min}$, the infiltration started from $54 \mathrm{~min}$. As the rainfall continued, the rainwater penetrated from the roadbed was less than the rainfall and the rainwater storage capacity of the pavement structure just like $5.5 \mathrm{~mm} / \mathrm{min}$. The rainfall lasted more than 14 hours from start to the end of the infiltration, and the infiltration rainfall was $438 \mathrm{~mm}$.

When the rainfall intensity was $3.4 \mathrm{~mm} / \mathrm{min}$ and $2.5 \mathrm{~mm} / \mathrm{min}$, the infiltration started from 67 minutes and 83 minutes, respectively. The rainfall lasted more than 14 hours from start to the end of the infiltration, and the infiltration rainfall was $294 \mathrm{~mm}$ and $190 \mathrm{~mm}$, respectively.

With the decreasing of rainfall intensity, the infiltration start time was delayed, and the soil infiltration became slower. It can also be seen from Figure 13 that the final water storage capacity of the pavement structure was the same under different rainfall intensity, when the pavement structure section type was the same.

As can be seen from Figure 13, the relationship between infiltration start time and the intensity of rainfall is as follows:

$$
y=1.1 x^{2}-21.7 x+130.2
$$

Adjusted $R$-square $=0.984, x$ is rainfall intensity, $\mathrm{mm} /$ minute; $y$ is infiltration start time, minute.

Within a certain rainfall intensity, the infiltration rate increases with the increasing of rainfall intensity.

The soil moisture in the early stage was constant and the amount of rainwater accumulated in a short period will change with the rainfall intensity, so that the pressure on the roadbed will be different, resulting in different rainwater infiltration rates. With the increase of rainfall, the speed of rainwater infiltration in the subgrade also increased and the infiltration start time was earlier.

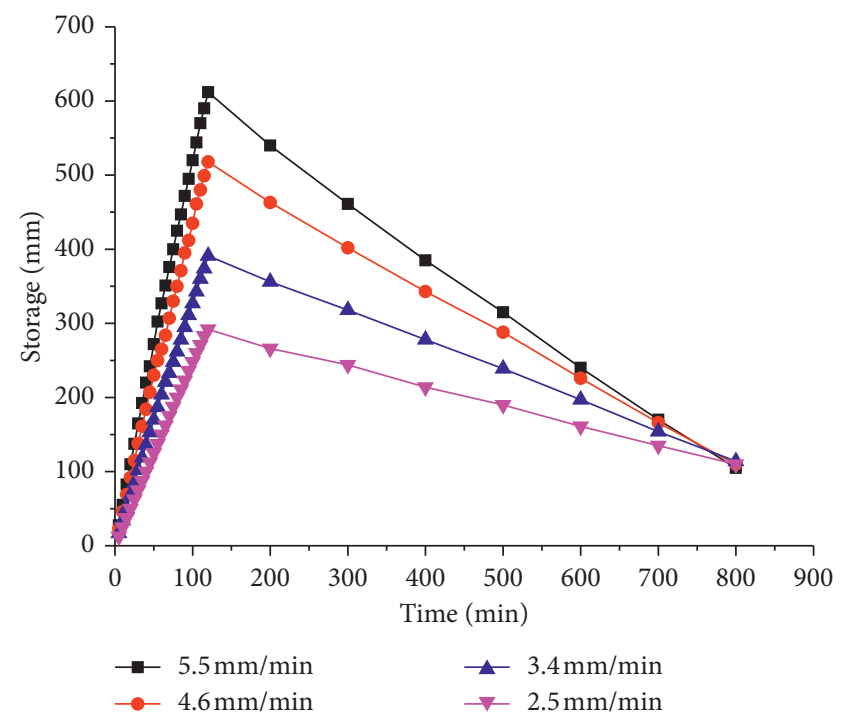

Figure 12: Relationship of storage under different rainfall intensities and time.

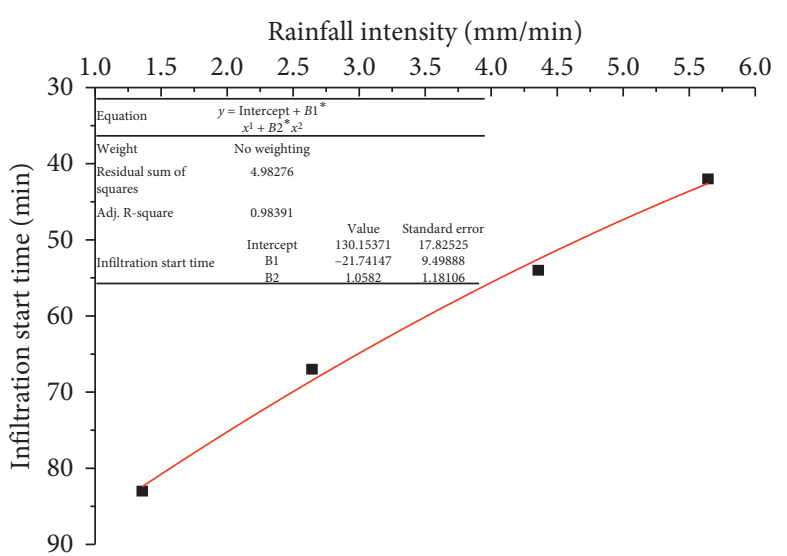

FIGURE 13: Relationship between rainfall intensity and infiltration start time.

6.4. The Analysis of Changes in Soil Moisture Content. Soil infiltration played an important role in the water cycle, which had great significance to the water resources, agricultural irrigations, and hydrological environment. Soil water infiltration was a dynamic process of water distributed in soil, so the change of soil water will affect the soil infiltration process [25-30].

6.4.1. During the Artificial Raining. According to Yanbin Guan's research on soil surface laminar flow [2], it was easy to meet the conditions for surface laminar flow formation, 
when the soil texture had obvious stratification. Rainwater penetrated into the surface layer of the ground and flowed into the lower flow channel after flowing transversely, whose velocity was slower than surface runoff. And the seepage law of the large-void asphalt pavement structure was similar to the above. The relationship between the soil water content in each layer and time under a rainfall intensity of $5.5 \mathrm{~mm} / \mathrm{min}$ is illustrated in Figure 14.

As can be seen from Figure 14, the soil water content of the depth of $10 \mathrm{~cm}, 20 \mathrm{~cm}, 30 \mathrm{~cm}$, and $40 \mathrm{~cm}$ was $5.2 \%, 4.6 \%$, $5 \%$, and $5.6 \%$, respectively, at the initial time. When the rainfall lasted 10 minutes, the soil water content was $20 \%$, $7.5 \%, 5.2 \%$, and $5.7 \%$, respectively, which indicated that a small amount of rain began to penetrate into the soil to depth $10 \mathrm{~cm}$. However, the soil water content did not reach a saturated state at 10 minutes.

As the rainfall continued, the rainwater penetrated further downward. After 40 minutes, the soil water content of the depth of $10 \mathrm{~cm}, 20 \mathrm{~cm}, 30 \mathrm{~cm}$, and $40 \mathrm{~cm}$ was $32.6 \%$, $32.2 \%, 29.5 \%$, and $28.1 \%$, respectively. From the experimental data in Figure 14, the soil water content of the entire roadbed tended to saturate, and the soil layer entered the stage of stable infiltration.

6.4.2. As the Artificial Raining Ended. When the rainwater stopped and the ground water was exhausted due to evaporation or infiltration, the water in the subgrade soil still needed to penetrate downward for a long time. During the infiltration process, water was redistributed in the soil profile. The soil layer saturated cannot retain all the water, so part of the water continued to move to the deeper soil layer due to suction gradient and gravity of the soil water [31-34].

As can be seen from Figure 15, the soil water content began to decrease slowly with the time increasing at the $10 \mathrm{~cm}$ soil depth.

The soil water content decreased greatly within 1-2 days and the decrease ratio reached $39.9 \%$ after ending artificial rainfall.

Similarly, the soil water content at the $200 \mathrm{~mm}, 300 \mathrm{~mm}$, and $40 \mathrm{~cm}$ soil depth decreased sequentially with time and the soil water content gradually tended to stabilize. In addition, the downward movement speed of the wet front was smaller found through the plexiglass side. The first reason is that the suction gradient between the two soil layers was correspondingly reduced, when the water of the moist soil layer was reduced and the water of the dry soil layer was increased. The second reason is that the dynamic process of soil moisture after infiltration became very complicated due to the existence of surface flow of large-void asphalt pavement.

6.4.3. Effect of Initial Water Content on Infiltration. The different initial water content of the soil will affect the infiltration of rain water and the runoff process [35-39]. So, four different initial soil moisture contents (5.3\%, 9.1\%, $12.8 \%$, and $16.1 \%$ ) were used to study the influence law with the same rainfall intensity of $5.5 \mathrm{~mm} / \mathrm{min}$. The test results are shown in Figure 16.

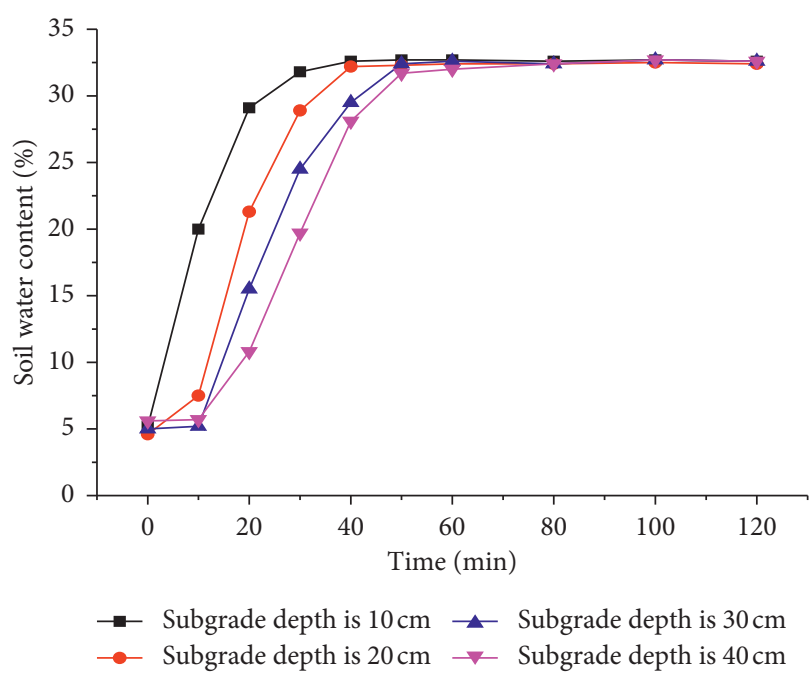

FIgURE 14: Relationship between soil water content and time.

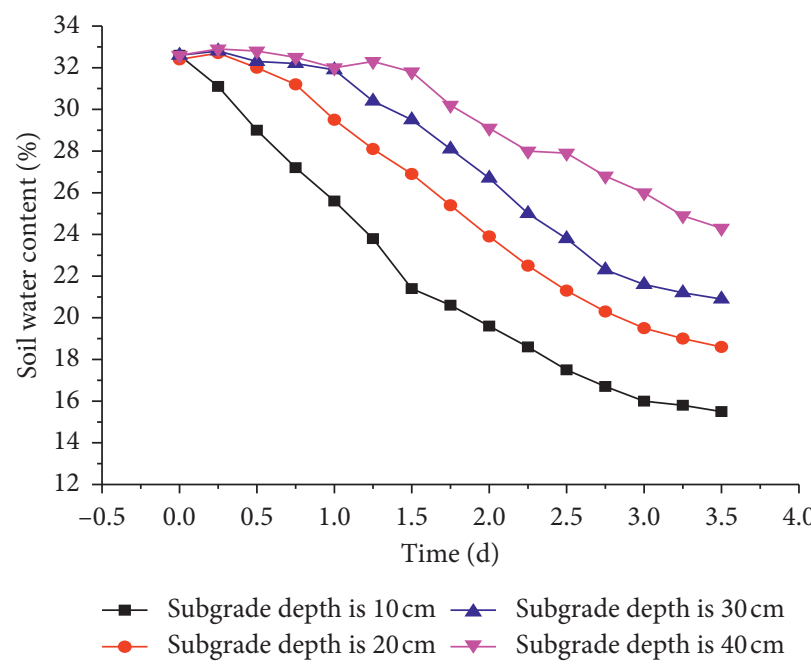

FIGURE 15: Relationship between soil water content and time at different soil depths.

As can be seen from Figure 16, the initial infiltration rate was the largest and soil saturation needs the longest rainfall duration, when the initial water content of the soil was $5.3 \%$. Mainly because the initial water content was low, the larger the magnitude of the matrix potential gradient, the larger the average suction force of the infiltration front. As the initial water content increased, the initial infiltration rate became smaller and the infiltration rate became shorter.

Combined with this experiment, when the initial soil moisture content was low, the soil moisture migration can be divided into two stages.

The first was the increasing stage of water content. After the wetting front moved to the layer, it was affected by gravity potential energy and matrix potential energy. The water content of the upper soil increased rapidly, but the water content did not reach saturation, and the soil moisture increased continuously. 


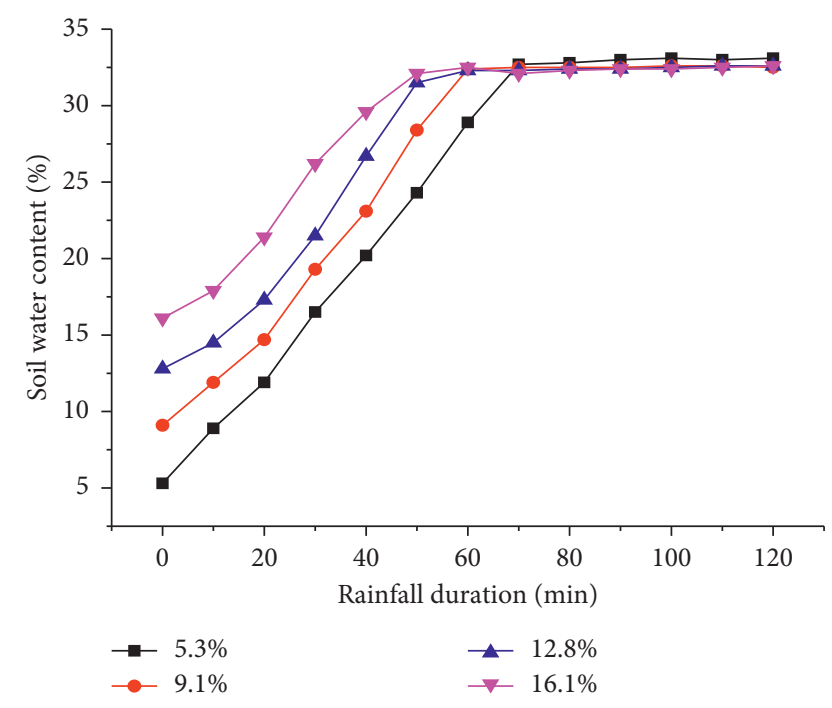

FIGURE 16: Effect of initial water content at $200 \mathrm{~mm}$ depth on infiltration.

The second stage was the stable stage of water content. When the soil moisture was close to saturation, the soil layer began stable infiltration, and the water flux of the soil layer became stable.

This is similar to Bodman's research on the initial water content of nonpermeable brick pavement soil [1].

\section{Conclusions}

The influence of several different pavement structures such as drainage pavements, semipermeable pavements, and permeable roads on surface runoff reduction was conducted. Secondly, the relationship between soil water content and rainfall duration was analyzed. Finally, the effect of initial water content on rainwater infiltration rates under different rainfall conditions was studied. The artificial rainfall device designed by authors was used to simulate rain on five types of pavement structures with 4 types of rainfall intensity. The conclusions are as follows:

(1) In the drainage pavement, the surface runoff coefficient of the dense asphalt pavement was more than $90 \%$, while the large-void asphalt pavement was less than $40 \%$ under different rainfall intensities, which means that the large-void asphalt pavement can effectively reduce the surface runoff.

(2) In semipermeable roads and permeable roads, the surface runoff coefficient at each rainfall intensity decreased with increase of the base layer thickness, mainly because the permeability of the cushion and soil foundation was relatively weak and the base layer stored some water and delayed the generation of surface runoff, when the rainfall lasted for a long time or the rainfall intensity was heavy.

(3) With the increase of rainfall intensity, the surface runoff coefficients of the three pavement structures increased and the surface runoff occurred earlier.
The sequence of the surface runoff generated in the three road structures was drainage road, semipermeable road, and permeable road.

(4) In the permeable road, the soil water content quickly reached a saturated state and a stable infiltration situation with the time increasing under the action of water gravity and the gradient of soil water suction. As the initial water content of the soil increased, the time of infiltration began to lag, and the amount of infiltration gradually decreased within 120 minutes of rainfall.

Groundwater level position, antifreezing layer, and traffic load condition will also affect the infiltration and drainage law of permeable pavement. In order to optimize the overall permeable performance of road surface, these factors need to be further studied in the future.

\section{Data Availability}

The data used to support the findings of this study are available from the corresponding author upon request.

\section{Conflicts of Interest}

The authors declare that they have no conflicts of interest.

\section{Acknowledgments}

This work was supported by the National Natural Science Foundation of China (51108151).

\section{References}

[1] H. R. Zhu, M. M. Yu, J. Q. Zhu, H. Z. Lu, and R. J. Cao, "Simulation study on effect of permeable pavement on reducing flood risk of urban runoff," International Journal of Transportation Science and Technology, vol. 132, pp. 121-130, 2018.

[2] Y. B. Guan, Water Permeability Mechanism and Structure Design of Large Porous Asphalt Pavement, Beijing Jiaotong University, Beijing, China, 2008.

[3] F. Gu, D. Watson, J. Moore, and N. Tran, "Evaluation of the benefits of open graded friction course: case study," Construction and Building Materials, vol. 189, pp. 131-143, 2018.

[4] Y. Xiong, "Analysis of the permeable asphalt pavement structure of urban roads," Urban Roads Bridges and Flood Control, vol. 33, no. 8, pp. 47-49, 2016.

[5] S. Saadeh, A. Ralla, Y. Al-Zubi, and R. Z. Wu, "Application of fully permeable pavements as a sustainable approach for mitigation of stormwater runoff," International Journal of Transportation Science and Technology, vol. 8, no. 4, pp. 338-350, 2019.

[6] L. Chu and T. F. Fwa, "Evaluation of surface infiltration performance of permeable pavements," Journal of Environmental Management, vol. 238, pp. 136-143, 2019.

[7] Q. Yang, S. Beecham, J. Liu, and D. Pezzaniti, “The influence of rainfall intensity and duration on sediment pathways and subsequent clogging in permeable pavements," Journal of Environmental Management, vol. 246, pp. 730-736, 2019.

[8] M. Legret and V. Colandini, "Effects of a porous pavement with reservoir structure on runoff water: water quality and fate 
of heavy metals," Water Science and Technology, vol. 39, no. 2, pp. 111-117, 1999.

[9] C. J. Pratt, J. D. G. Mantle, and P. A. Schofield, "UK research into the performance of permeable pavement, reservoir structures in controlling stormwater discharge quantity and quality," Water Science and Technology, vol. 32, no. 1, pp. 63-69, 1995.

[10] W. Jiang, A. Sha, J. Xiao, Y. Li, and Y. Huang, "Experimental study on filtration effect and mechanism of pavement runoff in permeable asphalt pavement," Construction and Building Materials, vol. 100, pp. 102-110, 2015.

[11] M. Koohmishi and G. Shafabakhsh, "Drainage potential of reservoir course of porous pavement for various particle size distributions of aggregate," Transportation Geotechnics, vol. 16, pp. 63-75, 2018.

[12] R. Zhong, Z. Leng, and C.-s. Poon, "Research and application of pervious concrete as a sustainable pavement material: a state-of-the-art and state-of-the-practice review," Construction and Building Materials, vol. 183, pp. 544-553, 2018.

[13] A. K. Chandrappa and K. P. Biligiri, "Pervious concrete as a sustainable pavement material - research findings and future prospects: a state-of-the-art review," Construction and Building Materials, vol. 111, pp. 262-274, 2016.

[14] M. Kayhanian, H. Li, J. T. Harvey, and X. Liang, "Application of permeable pavements in highways for stormwater runoff management and pollution prevention: California research experiences," International Journal of Transportation Science and Technology, vol. 8, no. 4, pp. 358-372, 2016.

[15] L. Z. Hou, S. Y. Feng, and Z. W. Han, "Effect of pervious brick pavement cushion structure on urban rainwater infiltration process," Journal of China Agricultural University, vol. 11, no. 4, pp. 83-88, 2006.

[16] E. Z. Bean, W. F. Hunt, and D. A. Bidelspach, "Field survey of permeable pavement surface infiltration rates," Journal of Irrigation and Drainage Engineering, vol. 133, no. 3, pp. 249-255, 2007.

[17] Z. C. Xu and Y. C. Guo, "Simulated experimental study on rainfall runoff with different underlying surface conditions in the city," South-to-North Water Transfer and Water Conservancy Science and Technology, vol. 1, pp. 64-66, 2007.

[18] Q. Z. Cai, Z. H. Chen, X. Chen et al., "Simulation of urban rainwater control effect with low impact development measures," Water Resources Protection, vol. 33, no. 2, pp. 31-36, 2017.

[19] F. Zhao, S. H. Zhang, J. G. Chen et al., "Research on rainwater infiltration collection and runoff reduction technology in permeable pavement," Water Supply and Drainage, vol. 37, no. S1, pp. S1254-S1258, 2011.

[20] CJJ/T 190-2012, Technical Specifications for Permeable Asphalt Pavement, China Construction Industry Press, Beijing, China, 2012.

[21] Z. Peng and L. Qingfu, "Effect of polypropylene fibre on mechanical and shrinkage properties of cement-stabilised macadam," International Journal of Pavement Engineering, vol. 10, no. 6, pp. 435-445, 2009.

[22] P. Peng Zhang and Q. Qingfu Li, "Experimental study on shrinkage properties of cement-stabilized macadam reinforced with polypropylene fiber," Journal of Reinforced Plastics and Composites, vol. 29, no. 12, pp. 1851-1860, 2010.

[23] P. Zhang, Q. Li, and H. Wei, "Investigation of flexural properties of cement-stabilized macadam reinforced with polypropylene fiber," Journal of Materials in Civil Engineering, vol. 22, no. 12, pp. 1282-1287, 2010.

[24] Y. Zheng, P. Zhang, Y. Cai, Z. Jin, and E. Moshtagh, "Cracking resistance and mechanical properties of basalt fibers reinforced cement-stabilized macadam," Composites Part B: Engineering, vol. 165, pp. 312-334, 2019.

[25] J. L. Zhang, L. L. Zhou, R. M. Ma et al., "Influence of soil moisture content and soil and water conservation measures on time to runoff initiation under different rainfall intensities," Catena, vol. 182, pp. 104-172, 2019.

[26] J. Norambuena-Contreras, G. Arbat, P. J. García Nieto, and D. Castro-Fresno, "Nonlinear numerical simulation of rainwater infiltration through road embankments by FEM," Applied Mathematics and Computation, vol. 219, no. 4, pp. 1843-1852, 2012.

[27] M. Kamali, M. Delkash, and M. Tajrishy, "Evaluation of permeable pavement responses to urban surface runoff," Journal of Environmental Management, vol. 187, pp. 43-53, 2017.

[28] C. Zeng, Q. J. Wang, and J. Fan, "Effect of initial water content on soil vertical line source infiltration characteristics," Transactions of the Chinese Society of Agricultural Engineering, vol. 26, pp. 24-30, 2010.

[29] Y. Liu, Y. Xin, Y. Xie, and W. Wang, "Effects of slope and rainfall intensity on runoff and soil erosion from furrow diking under simulated rainfall," Catena, vol. 177, pp. 92-100, 2019.

[30] H. S. Chen, M. Shao, and Y. Xie, "Effects of initial soil moisture content on rainfall infiltration on slope and soil water redistribution," Transactions of the Chinese Society of Agricultural Engineering, vol. 22, no. 1, pp. 44-47, 2006.

[31] N. Xie, M. Akin, and X. Shi, "Permeable concrete pavements: a review of environmental benefits and durability," Journal of Cleaner Production, vol. 210, pp. 1605-1621, 2019.

[32] T. Lucke, F. Boogaard, and F. van de Ven, "Evaluation of a new experimental test procedure to more accurately determine the surface infiltration rate of permeable pavement systems," Urban, Planning and Transport Research, vol. 2, no. 1, pp. 22-35, 2014.

[33] L. Chu, B. Tang, and T. F. Fwa, "Evaluation of functional characteristics of laboratory mix design of porous pavement materials," Construction and Building Materials, vol. 191, pp. 281-289, 2018.

[34] L. Gholami, N. Karimi, and A. Kavian, "Soil and water conservation using biochar and various soil moisture in laboratory conditions," Catena, vol. 182, pp. 104-151, 2019.

[35] L. Zhao, R. Hou, F. Wu, and S. Keesstra, "Effect of soil surface roughness on infiltration water, ponding and runoff on tilled soils under rainfall simulation experiments," Soil and Tillage Research, vol. 179, pp. 47-53, 2018.

[36] H. Liu, T. W. Lei, and J. Zhao, "Effects of initial soil moisture content and rainfall intensity on infiltration performance of clay loess," Science of Soil and Water Conservation, vol. 7, pp. 1-6, 2009.

[37] C. Hernández-Crespo, M. Fernández-Gonzalvo, M. Martín, and I. Andrés-Doménech, "Influence of rainfall intensity and pollution build-up levels on water quality and quantity response of permeable pavements," Science of the Total Environment, vol. 684, pp. 303-313, 2019.

[38] M. X. Liu, Y. Nie, and J. Yu, "Infiltration process of clayey soil under different initial moisture content," Acta Ecologica Sinica, vol. 32, pp. 871-878, 2012.

[39] L. L. Song, J. F. Zhang, and R. Gao, "Effect of the initial moisture content of the upper soil layer on the water infiltration in the middle finger flow of layered soil," Journal of China Agricultural University, vol. 18, pp. 174-181, 2013. 